\title{
Elementary students' perspectives on a curriculum for literacy education
}

\section{Íris Susana Pires Pereira \& Xosé Antón González Riaño}

To cite this article: Íris Susana Pires Pereira \& Xosé Antón González Riaño (2018) Elementary students' perspectives on a curriculum for literacy education, Research Papers in Education, 33:1, 89-112, DOI: $10.1080 / 02671522.2016 .1270999$

To link to this article: https://doi.org/10.1080/02671522.2016.1270999

曲 Published online: 28 Dec 2016.

Submit your article to this journal $\pi$

Џll Article views: 69

Q View related articles $\square$

View Crossmark data ¿ 


\title{
Elementary students' perspectives on a curriculum for literacy education*
}

\author{
Íris Susana Pires Pereira a and Xosé Antón González Riaño ${ }^{b}$

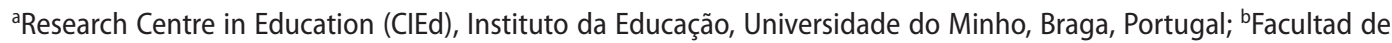 \\ Formación del Profesorado y Educación, Universidad de Oviedo, Oviedo, Spain
}

\begin{abstract}
This article arises out of an initiative to implement a curriculum designed to enhance the literacy learning of elementary school children in Portugal. Researchers explored students' perspectives about the experienced curriculum through the enactment of group interviews. Thematic analysis of the conversations revealed positive opinions and feelings about the learning experience. It further showed students' representations about the experienced curriculum, namely their acute awareness of the specialised dimensions of language that shaped the learning content and the importance of such learning. The analysis unveiled the key role students attributed to situated playful practice in the learning process, side by side with agency, collaboration and ICT mediation. Explicit learning, transformed practice and formative forms of assessment were other valued pedagogical dimensions. On the whole, this research brings empirical support to a sociocultural understanding of a literacy curriculum for elementary grades, an original contribution made from the perspectives of learners themselves.
\end{abstract}

ARTICLE HISTORY

Received 19 September 2015

Accepted 8 October 2016

\section{KEYWORDS}

Elementary school education; literacy curriculum; group child interview; children's perspectives; specialised language; play

This article arises out of a governmental initiative to implement a curriculum designed to enhance the literacy learning of elementary school in Portugal (National Programme for the Teaching of Portuguese; henceforth PNEP). PNEP was implemented from 2006 to 2010 with the aim of improving 'the conditions of language and literacy teaching and learning in order to improve reading comprehension, oral expression and writing in elementary schools' (Law number 546/2007, Diário da República, $2 .{ }^{a}$ série $-N .^{\circ} 8$ - 11th January, 2007, 899). The Portuguese Government at the time justified this national-scale intervention due to elementary students' low results in literacy in national testing from 2000 to 2005. Other similar results, such as the international literacy studies in which Portugal had participated (Reading Literacy - IEA, 1992; PISA 2000 e 2003), were also evoked to justify its implementation.

PNEP was an in-service teacher education programme explicitly based on the principle that students' learning is affected by teacher education levels (Yoon et al. 2007). It involved the establishment of professional networks comprising teachers who were participating in the project as learners or trainers and academics that coordinated its implementation at high education institutions and universities all over the country. The later were made responsible for the enactment of a centrally-designed contents plan, for preparing teacher trainers and for close monitoring the implementation of the trainees' learning, which took place in schools through the intervention of teacher trainers. 
Besides aiming to develop the literacy learning and teaching, the Portuguese Government wanted to stimulate, in the academic institutions involved, the development of research in the field of language and literacy education in the elementary years (CNA 2006). This text results from the research developed by the coordination centre located at the University of Minho (Northern part of Portugal), of which the first author was responsible for two years (Pereira 2010a). During that period, she supported teachers, either immediately working with her as trainers or as trainees, in schools, to develop a thorough understanding of the complexities of a curriculum for literacy education in elementary grades based upon sociocultural perspectives. Such broad view was not explicit in the initial governmental plan, which nevertheless allowed space for such elaboration. Therefore, PNEP became an exceptional opportunity for experimenting and researching the effectiveness of such understanding. When PNEP came to an end, a research project was set with the aim of identifying the central features of the literacy curriculum for elementary grades from the perspectives of learners' themselves for reasons that will be made clear. This research is presented in this article.

\section{A curriculum for elementary school literacy learning: essential tenets}

The literacy curriculum for elementary education that was enacted in our coordination centre was designed upon central questions such as why, what, what for and how to teach literacy and how to assess students' literacy learning (Pereira 2010b; Reid 1999). A sociocultural view of language and literacy sustains the answers to these questions (Vygotsky 1979, 1995), though the curriculum has a notoriously eclectic nature (Schwab [1970] 2013) due to other theoretical influences, especially from Systemic Functional Linguistics and Socioconstructivism.

\section{Literacy curriculum in the elementary grades: justification and contents}

Vygotsky (1995) conceived of language as a fundamental mediating tool in the transference of culture, from an inter-mental into an intra-mental plane, resulting in the development of human cognition (Wertsch 1991). This understanding, together with complementary linguistic contributions (Gee 2007; Halliday 1993; Schleppegrell 2004), was central in the elucidation of the reasons that justify and contents for literacy learning in elementary grades.

Halliday (1993) affirms that, 'When children learn language, they are not simply engaging in one learning among many; rather, they are learning the foundation of learning itself' (93). In fact, at school, the object of such learning is a cultural development of language that has been referred to as specialised language or the language of schooling (Pereira 2010b; Gee 2010; Halliday 1993; Schleppegrell 2004). The cultural dimension of language is an inevitable consequence of the historical development of human communities (Halliday 1993; Heath 1983). In effect, the development of human culture has been reflected in the (re)configuration of increasingly specialised meanings, such as descriptions and classifications, explanations and abstract discussions, in science; symbolic representations of the complexities of the human existence, elaborated in literature; or the various regulations that order our social life, for example. In response, language has been renewing its meaning making potential by constituting specialised languages (Halliday and Martin 1993). Bearing this in mind, Halliday (1993) convincingly argued that, 'at school learning is learning to mean, and to expand one's meaning potential' (Halliday 1993, 112, 113, original bold). In similar terms, Gee (2010) argues that the learning of specialised languages 'is the basis to keep up with the ever-increasing demands for learning content in school via complex technical and academic varieties of language' (184). On the whole, this argument illuminates the main reason for assuming the specialised dimension of language as the main object of learning in the literacy curriculum at the same time that it sustains current definitions of literacy as the set of meaning making practices that make use of the specialised languages in as many social areas of specialised linguistic action, also conceptualised as multiliteracies (Cope and Kalantzis 2009, 2010.

Most students begin their encounters with such languages at school (Gee 2004; Heath 1983). Although their vernacular language features all the necessary linguistic potential for ordinary meaning 
making, it does not usually feature the necessary tools for constructing the scientific concepts that are later learnt at school. Yet, traditional school has been denounced for not preparing all children for the increasing academic language demands, causing 'The fourth grade slump' (Gee 2004, 2010). This is a powerful subsidiary reason for assuming the cultural dimension of language as a learning object, and a crucial one for literacy curricula for elementary school grades. As Gee convincingly puts it, defending the formal learning of specialised language from elementary school onwards is not the apology for the teaching of standard varieties, rather 'it is a claim that even native speakers of vernacular Standard English need language learning to prepare for specialist varieties of language' (Gee 2010, 180; Pereira 2010b).

Code, text and grammar constitute the basic categories of the specialised language as a learning content in a literacy curriculum in the elementary grades (Pereira 2010b). Each category of contents represents relevant domains of cultural-historical development of language, each with its own specialised dimensions, the learning of which is therefore expected to begin at elementary grades. For instance, in cultures that use the alphabetic principle of written representation, knowledge of the written code implies knowing units (which represent sounds), rules of use as well as specific mental processes implied in written word identification and representation (Coltheart et al. 1993; Ellis 1989). Textual knowledge entails the knowledge of literary and non-literary genres and its relevant linguistic features (Bahktin 1986; Schleppegrell 2004) as well as basic processes for textual meaning making (Rasinski and Padak 2004), either receptively (for instance, in reading comprehension processes [Irwin 2007]) or productively (as in text process writing (Flower and Hayes 2003).

\section{Literacy curriculum in the elementary grades: pedagogical assumptions}

In a sociocultural framework, cultural learning is assumed to follow a definite cycle of development, from social learning into individual internalisation (Vygotsky 1979). This tenet has been the basis of recent conceptualisations regarding the pedagogy of literacy as found in the context of the New Literacy Studies (Gee 2010). The pedagogical principles of situated practice, explicit teaching and transformed situated practice configure the learning-circle for the learning and internalisation of specialised languages (Cope and Kalantzis 2009, 2010; The New London Group 2000; Schleppegrell 2004). They combine learning by 'social doing' with 'conscious knowing'.

Situated practice claims for a contextualised use of specialised languages. It establishes that any specialised language is tacitly learned at school when it is 'married closely to specific and connected actions' (Gee 2010,183) to make specialised meanings of interest to the learner, even if merely simulated in the classroom.

Currently, ICT devices and resources are inescapable in any discussion of situated literacy practices. ICT have transformed the communicational practices that make use of specialised language, in particular due to its unprecedented multimodal nature and enhancement of social connection, which repercussions in the construction of human cognition (Cope and Kalantzis 2010). ICT therefore have an instrumental role to play in the enhancement of literacy practices and learning (Dede 2000; Gee 2010).

Explicit learning, often referred to as direct instruction (Rasinski and Padak 2004; Rupley, Blair, and Nichols 2009), plays a detached role in the sociocultural learning theory. It is deeply rooted in Vygotsky's conception of the development of human consciousness (Holquist 2002). When he guides learners' attention to contents of learning, the teacher performs 'a loan of consciousness' from his 'monopoly of foresight' (Bruner 1986, 75, 76, as cited in Holquist 2002, 82). Vygotsky (1995) claims that the development of higher mental functions as well as of the tools that allow their development (as is the case of specialised language) is powered by such conscious learning. In the case of the learning of specialised languages, one condition for the explicit intervention is that it is rooted in the context of specialised meaning making practice (Gee 2010; Schleppegrell 2004). The teacher turns fundamental dimensions of specialised language that are being used visible for learners in order to support the development of their awareness and conscious learning of such cultural contents. Like any other cultural 
content, specialised language might otherwise be very difficult to learn on one's own, especially for children who do not practice it at home (Gee 2004, 2010). Vygotsky was also clear that the instructive dialogue that frames explicit learning should actively construct a Zone of Proximal Development for learners. When he says that 'the only good instruction is that which goes ahead of development and directs it' (Vygotsky 1995, 181, our translation), Vygotsky is asking for the configuration of challenging learning contexts. Collaboration is thus a central dimension in the configuration of the ZDP (thus of situated practice), which Vygotsky clearly put when he claimed that children can do more than they would do by themselves if, in the context of participation in challenging activities, they receive help that activates their maturing capabilities 'through their dialogue with teachers or more capable peers' (Vygotsky 1995, 180, our translation).

Transformed situated practice establishes that any explicit learning concerning specialised language ought to be independently and consciously applied in new, real (and now reflected) situations of specialised meaning making so that the cycle of its cognitive internalisation is complete (Cope and Kalantzis 2009, 2010; The New London Group 2000).

These pedagogical principles were studied during the enactment of the literacy curriculum, but a sociocultural approach cannot overlook the specificities of the age group involved, in our case elementary school children, nor the role of play in their learning processes, as also conceptualised by Vygotsky. When referring to the explicit intervention of teachers, he clearly noted that it should be 'based on the needs of children' and 'not presented from outside, from the hands of the teacher' (Vygotsky 1979, 160, our translation). In his theory, the learning needs of children have their roots in play. He stated that, 'The child moves forward essentially through play activity' (Vygotsky 1979, 156, our translation). Play is the primary way in which children engage with the world, which does not disappear during elementary school years (Vygotsky 1979; Kravtsova 2014). It has been the subject of a multifaceted research agenda (Brooker, Blaise, and Edwards 2014), of which three main tenets are relevant for the conception of situated literacy practice.

Play is a fundamental activity format for human enculturation (Vygotsky 1979). Van Oers (2014) argues that play is 'basically a way of executing practices, not a special phenomenon that may exist outside practices or precede them' (60). Children routinely engage in the action potentials of the adult cultural situations that they imaginatively recreate in the play in which they fully engage (Van Oers 2014).

Play evolves in definite periods in the ontogenesis (Kravtsova 2014). When pre-school years come to an end, 'the rules of play come to the forefront and the imaginative situation moves towards the sidelines' (Kravtsova 2014, 25, 26). This is the period in which games with rules appear as play practices (with the consequent need for the explicit learning of such rules), which leads Kravtsova to affirm that, 'on a large scale, all learning activity of primary school children is play with rules' (Kravtsova 2014 , 29). During this period, former forms of play, most notably pretence role-play, in which rules are also involved, do not disappear; instead, they also begin to change as 'the content of play often becomes related to real life and real events' (Kravtsova 2014, 26). Simply put, having had the experience of playing fully invented activities (for instance, playing to be a fireman or Lightning Mcqueen), elementary school children appear to be ontogenetically 'ready to accept' rules in play activities that have their origin in real life and are connected to their own identities as real-life subjects.

Play has been 'positioned as educational practice' (Wood 2014, 147). Wood (2014) offers a categorisation of three modes in which play can been enacted as pedagogy: A, child initiated play; B, adult-guided play; and C: technicist/policy driven version of the educational play. These modes differ in what concerns to who takes decisions (the child; the educator who follows the curriculum but is responsive to children's needs and purposes; or the curriculum, respectively); to consequences regarding the learning outcomes (meanings constructed by children according to their interests; meanings constructed in the interplay of children's and the educators' purposes; or meanings exclusively defined by the curriculum, respectively); and to the format of enacted play activities (free; structured by educators; or structured and programmed by the curriculum, respectively). 


\section{Literacy curriculum in the elementary grades: assessment}

Formative forms of assessment, which consist in assessing for learning (Carr 2014), involve the collection of data about students' learning with the main aim of taking situated pedagogical decisions (Black and William 1998). Formative forms of assessment of literacy learning involve teachers and learners in active and interrelated roles. Besides preparing situated, explicit and transformed learning contexts, teachers are expected to analyse the result of their students' efforts on spot by observing their literacy learning practices in order to adjust their intervention and provide feedback to the immediate needs. On the other hand, students distribute their activity between involving in the learning that the teacher prepares and monitoring their own learning levels, thus developing self-awareness of achievements and needs in a responsive and responsible way, which allows their learning perceptions to be fully integrated into the whole pedagogical process (Broström 2006). As such it is an integral part of the sociocultural vision of the literacy education presented so far. In particular, it is a crucial dimension of the construction of the ZPD, besides being clearly dependent on explicit content learning and playing an important role in the construction of learners' conscious learning and situated transformed practices.

\section{Literacy curriculum in the elementary grades: aims}

The development of an autonomous mind is a major educational aim of a sociocultural process of human learning. Vygotsky stated that, 'What the child can do today in cooperation may do so alone tomorrow' (1995, 181, our translation), allowing her to engage in self-initiated, purposeful behaviour in challenging situations' (Meyers and Berk 2014, 43). As envisaged by Vygotsky, such an autonomous mind is self-regulated, making a conscious, reflected and strategic use of all the internalised cultural knowledge (re)constructed in the intra-mental plane (Meyers and Berk 2014).

Within our framework, the aim of specialised language learning in a literacy curriculum can be conceived as the enablement of future citizens to (i) self-engage in different literacy practices by reading, writing, orally expressing and listening to specialised texts; (ii) regulate the construction of meanings in those situations, using their conscious language knowledge in challenging situations; and (iii) think, speak and write about language and literacy itself (Pereira 2010b). Yet, when learners are actually beginning their apprenticeship of literacy practices, the goal of a literacy curriculum is best conceived of as the preparation for 'a successful trajectory throughout the school years also beyond' (Gee 2010, 175). Gee argues that, 'Children need to get ready for [the] increasing language demands as early as possible' (Gee 2010). Seen from this perspective, the learning of specialised language learning at elementary school is a forward looking endeavour, intending to avoid the fourth grade slump by offering the possibility to every learner of 'being able to handle increasingly complex language, especially in the content areas (e.g. science and math) as school progresses' (Gee 2010).

\section{Research}

During 2008-2009 and 2009-2010, this understanding of literacy education in the elementary grades was discussed with trainers apropos each of the major themes in which the in-service programme was organised, namely: (i) ITC and literacy learning; (ii) Code learning; (iii) Text learning; (iv) Grammar learning; (v) Assessment. During each school year, trainees gradually studied the same understanding in a cycle comprised of learning sessions and reflective practice close supervised by trainers, consisting in the application of knowledge to the planning, enactment and analysis of classes intended to improve students' literacy learning.

In 2009-2010, 33 teacher trainers, 435 teachers and 7887 students were coordinated at our centre. Throughout that period, an intuition about the practicability of the curriculum rationale (Schwab [1970] 2013) presented above, based on extensive informal reports of the apparent success with which it was reaching its ultimate targets (the students), prompted the emergence of the following main research question: What can we learn about a curriculum for literacy education in elementary school 
years by inquiring these learners? We wanted to know what they thought about it, in particular what they valued the most, with the aim of identifying relevant features for conceiving a literacy curriculum for elementary grades. The interest of carrying out such inquiry was also stirred by current assumptions about doing research with children, particularly those which claim close attention to children's voices, assuming them to be experts on their lives (Einarsdottir 2014; Fargas-Malet et al. 2010; Lewis 1992; Shaw, Brady, and Davey 2011). The acknowledgement that not much is known about students' perspectives on their educational experiences and, to our knowledge, that no research has focused on students' representations about any similar literacy learning experience at elementary grades, finally stimulated the enactment of the research.

\section{Research design}

We designed and implemented a qualitative research to answer our main research question, which we divided into the following five sub-questions:

(1) Which opinions and feelings did students build about PNEP classes?

(2) Which and how consciously was the learning of specialised language contents perceived by learners?

(3) Which representations about the aim of literacy learning did students develop?

(4) Which features of the experienced process were perceived as relevant for literacy learning?

(5) Which representations about assessment of literacy learning did children construct?

\section{Research methods}

In order to answer to the research question, we prepared a qualitative study that closely followed the methodological and ethical guidelines for researching children (Shaw, Brady, and Davey 2011). We chose to interview students as a data collection procedure.

Child group interviews are particularly adequate when intending to involve children as informants about their own lived experience (Cohen, Manion, and Morrison 2011; Einarsdottir 2014; Lewis 1992). They offer the possibility of rapidly and efficiently collecting rich information in groups of people who 'have been working together for some time or common purpose' (Watts and Ebbutt 1987; cited in Cohen, Manion, and Morrison 2011,373). The fact that the whole group can interact during the interview also allows that children support, elaborate and detail individual reflections, thus contributing to the construction of a collective perspective (Cohen, Manion, and Morrison 2011; Lewis 1992). At the same time that it justifies the option for group interviews, this set of reasons also explains why other techniques, such as individual interviews or focus group, were discarded for data gathering, although relevant features of both were taken into account to enrich group interviewing.

\section{Preparing and enacting group interviews}

Interviews were organised to drive group thinking into issues that would produce relevant data to answer each of the research sub-questions. The first interview question elicited students' general opinion, followed by a second question asking for the identification of what the students liked the most and the least, probing them for justifications and examples. With these, we intended to characterise children's opinions and feelings (sub-question 1). Children were also asked about what they learnt, probing them to identify and justify especially interesting and important learning for themselves, from which we intended to be able to describe their perception about their learning of specialised language (sub-question 2) as well as characterise their representations about the aims for literacy learning (sub-question 3). Finally, children were asked to say if they thought that classes were different (closed question), followed by a follow-up question asking for their reasons. The decision to confront children 
with this idea ('classes were different') echoed a frequent appreciation made by students and reported by trainers. Through this question, we intended to identify features of the learning process that justified such differentiation (sub-questions 4 and 5). Questions were articulated from students' perspectives and not from our theoretical point of view, and they presented patterns of language and vocabulary that were piloted for children's understanding (Cohen, Manion, and Morrison 2011; Saywitz and Camparo 2014; Shaw, Brady, and Davey 2011).

We assumed that the relationship of proximity that had been held for at least one academic year among students and teachers and teacher trainers, reported at the coordination centre to be overwhelmingly friendly, would guarantee rapport (balance in the power of interviewer and interviewed) and trust, allowing children to reveal their thinking (Einarsdottir 2014; Fargas-Malet et al. 2010; Saywitz and Camparo 2014). For that reason we asked trainers and teachers to assume the role of interview facilitators. They were handed in the written outline for the group interview. We guided them to help children understand that the interviews were informal conversations aimed at collecting their perspectives on classes and not at evaluating them (either students' or teachers'), underlying that every answer was welcome (Morgan et al. 2002; Saywitz and Camparo 2014; Shaw, Brady, and Davey 2011). We also asked them to check whether children understood questions and to check for clarity in children's answers (Saywitz and Camparo 2014). With these precautions we intended to minimise potential distractions, susceptibilities and language limitations (Lewis 1992). Since these interviews concerned an educational process in which children participated as part of their regular yearlong educational experiences, no informed consent was deemed necessary (Shaw, Brady, and Davey 2011), beyond asking them about their willingness to jointly do the task. We asked that interviews were held in children's usual classrooms, a natural and non-disruptive setting to ensure children's comfort in a friendly atmosphere (Cohen, Manion, and Morrison 2011; Lewis 1992). Our research became close to an ethnographic study (San Fabián 2014; Saywitz and Camparo 2014) because interviews were designed to allow us to describe and explain students' perspectives about their lived, educational experiences in their natural context of occurrence.

Interviews targeted all 2 nd to 4 th graders involved in the programme ( $2 \mathrm{nd} n=2095 ; 3 \mathrm{rd} n=1880$; 4 th $n=2019)$, and we suggested that first grade teachers decided about their students $(n=1893)$ capacity to participate. Teachers audio recorded and, in some cases, video recorded the conversations.

We gathered 128 group conversations, amounting to 31:23:37 (hours:minutes:seconds) of recording time. Nineteen different teacher trainers were represented, and 2365 students of mixed gender were potentially involved, with an average of 188 students per class. Fifty-one classes were urban and 77 transitional. The label urban was attributed to schools located in cities or else at the centre of smaller municipalities, whereas schools located in villages with close rural backgrounds were labelled as transitional. As participation in the official teacher training programme was open, the high levels of participation among transitional schools can only be justified by these schools' high commitment with the improvement of their students' educational achievement and, for that matter, with their institutional status too.

\section{Selecting interviews for transcription}

There was a deliberate preliminary analysis of interviews to reduce the corpus to highly informative examples regarding the research question. The selection was based on a set of formal as well as of content criteria (Cohen, Manion, and Morrison 2011; Fargas-Malet et al. 2010; Lewis 1992; Saywitz and Camparo 2014).

The formal criteria were defined in accordance with the main recommendations on conducting group interviews, though some were adapted from discussions about focus group (Krueger 1991). Interviews were selected per class (thus targeting a natural and already collaborative group), each with a single grade (thus trying to keep the data as homogeneous as possible), with several children intervening (thus denoting the existence of rapport among discussion facilitators and participants). We also looked for interviews that had a well-defined beginning and end, offering enough contextualisation 
for the listener to perceive the flow of dialogue and that were maximally explicit and informative on their own. We also looked for the existence of focus during the conversation, which is taken as an indicator of children's attention and interest (Shaw, Brady, and Davey 2011). Finally, we also traced the existence of intersubjectivity (Anderson 2008). Although subjective perspectives about common issues under research were evidently expected and valued, we paid special attention to the existence of interaction through which children prompted their colleagues' interventions, thus contributing to the construction of a common, collective and consensual understanding about the issues under research (Cohen, Manion, and Morrison 2011).

The content criteria were defined considering the meanings that were under inquiry so that the most informative interviews were identified, namely: (i) expression of opinions and feelings; (ii) reference to the learning constructed; (iii) reference to features of the learning process; (iv) reference to assessment processes; (v) formulation of the personal value of the learning constructed. We used an analytical grid (schematised in Table 1) to perform this preliminary corpus analysis.

The results of the analysis performed by the two authors of the paper were triangulated with those of an independent ratter, a voluntary primary teacher who had not been involved in the in-service initiative. We found 16 mixed-grade classes and 29 recordings for which grades could not be identified. Only the 58 homogeneous classes were coded for the remaining criteria.

The results of the application of the remaining formal criteria revealed that it was relatively easy to hold a straightforward and focused conversation about the classes and to construct a shared, collective opinion. Besides, they revealed that it was relatively less easy for facilitators to keep a constant high pattern of intersubjectivity among students, perhaps due to the influence of more traditional school interaction routines and patterns that might restrain and conform students' participation.

The application of Table 1 permitted the identification of 34 interviews to be the most content informative, all rating from 10 to 19 items in the analytical grid. We ultimately triangulated these content results with the results of the application of the formal criteria, and we finally identified 19 interviews as maximally relevant for transcription. This procedure allowed the identification of five interviews per grade, except for the third grade, which was represented by four classes. The largest interview that was transcribed was 1:00:54 long, and the shortest was 00:06:49.

In the transcriptions, we made all efforts to distinguish individual contributors to dialogues and to preserve anonymity, as extensively claimed in the relevant literature. A code was attributed to each student (C), teacher (T) and excerpt, for example 4XPZ6; 4XP1_6, consisting of grade (4) + teacher trainer's initials (XP) + trainee's initials (Z) (or a number (1), if the trainee's id was not available) + page (6).

Finally, we thematic analysed the transcribed interviews to identify and summarise key features of our body of data (Braun and Clarke 2006). The theoretical synthesis about the curriculum for literacy education that sustained the coordination of the programme guided the analytical process, though it remained fully open to the emergence of new themes. The excerpts were translated from Portuguese and adapted to facilitate legibility.

\section{Findings}

The analytical process revealed an evident variability in the quality of the information among interviews according to school grade as well as a fertile set of themes regarding each of the dimensions that were targeted in the interview. In fact, most of the central themes about opinions and feelings, perception of specialised learning constructed, perception of learning process and, though in a less extensive way, perceptions about assessment and the importance of literacy learning were common and recurrent. Few themes emerged only in specific grades. Also of interest was the acknowledgement of the existence of multiple sources of evidence to characterise each dimension under research coming from children's answers to different interview questions. 


\section{Which opinions and feelings did students build about classes?}

Children liked PNEP classes a lot. Their voices revealed a general very high positive representation about the learning context that it offered them, with which they associated a clear feeling of happiness and an evident engagement.

Classes were consensually perceived as a very motivating experience. Students expressed very good opinions (classes were good, great, wonderful, nice, exciting, motivating, important, magical ...), and affectionate feelings (liked PNEP a lot, loved, enjoyed ...), which they mostly justified and detailed by referring to what they learned as well to how they learned, and in some cases with a mix of such justifications. In the following excerpt from a 1st grade, C7's answer shows that she is clearly manifesting her own affectionate opinion, which emphatically goes beyond her teacher's prompt:

T: Child 7, did you like classes?

C7: I didn't like them; I loved them!

T: Oh, really? And why was that?

C7: Because we always did different classes and we were always learning.

C9: I liked to work with everyone, all the tasks. (1AL4)

In this excerpt, $\mathrm{C} 9$ cannot help but intervening to add her own reasons, thus contributing to the construction of intersubjectivity that was expected of group meaning construction. This commitment was actually constant among groups. A 4th grader said, 'These classes were very funny, I think they should have been done more often, they were very creative and one thing I am sure: they were much better than copying [texts]!' (4ARG1). In the following excerpt, the teacher scaffolds C5 to summarise the opinion that she had been giving by using an adjective ('adjectives' had been referred to before in the conversation as objects of new learning). Another child cannot help but intervening with her own adjective (new):

T: Tell me in a word: How would you describe PNEP? PNEP for you was ... See, now you're going around an adjective!

C5: Very cool!

C7: I think PNEP was ... was ... a new thing that I never had ... I had never seen before ... had never participated in a class like this ... I think it was new and I hope ... I hope to do it again. (4ARD2)

Some minutes later, when the interview was actually coming to an end, these same students got very emotional when the teacher confronted them with a sequence of $p p t$ slides (video) with photos of working sessions, a prompt that the teacher herself decided to use:

T: C7, what did you think of the video?

C7: I think the video made us see what we learned and I think now I'll never forget the lessons. PNEP was very striking.

T: And those boys who cried! All were moved, I think ... But why crying? It is a sad video?

C5: It's crying out of happiness [very emotional].

T: Oh! Go on, C5.

C5: It is joyful crying!

T: Crying out of joy!? Why?

C5: We are working well and ... [he cries]. (4ARD16) 


\section{Which and how consciously was the learning of specialised language contents perceived by learners?}

Throughout the interviews, students said that they made 'great learnings' (4ARP5) or that they 'learned many things' (1CM3_1). Our analysis revealed that students were well aware of contents they had learned concerning code, text and grammar, which were profusely referred to and specified in all grades. However, an expected difference was found regarding the reference to these contents among grades, as learning related to code was more frequently referred to among first and second graders. We further realised that students' awareness manifested itself in different ways: Students perceived classes as supporting the construction of language knowledge that was new and they also perceived classes to help them improve previous knowledge.

\section{Code, text, grammar as new knowledge}

The reference to new learning concerning several dimensions of specialised language was constant in all grades, as illustrated in these examples:

(Code, word units) C10: We learned the letters. (1CM1_1)

(Code: phonological awareness): C14: I learned the sounds of letters. (2CA4)

(Code, word identification) C6: I liked the class when we took the words from the little box because I learned to read those words. (1AR5)

(Text: oral production) C4: In the class of telling stories I learned to tell stories. (1AR_7)

(Text: reading) C7: I liked to learn how to read quickly. (2AL4)

(Code: units; Text: reading; text types and process writing) C7: We learned new sounds of letters, learned to write several different types of texts, to understand the texts ... Ah! [we learned] to write texts: to do the brainstorming, planning, drafting and then the reviewing. (3VL2)

(Text, writing; Grammar) C11: The lesson I learned the most was when we wrote a text. We also did an exercise that was Divide the words into two groups and I learned about nouns. I did not know that, I had never heard about that before. (2IL7)

(Text: types and features) C9: In the news article there is several information ... some is more important and other less ... and the most important comes first (3AL5).

(Text: text types) C2: I greatly appreciated PNEP classes because they were more creative and we made new things such as stories, biographies, poems that we didn't even know we were able to do at all. (4ARG5)

\section{Code, text, grammar as improved knowledge}

There was also a widespread reference to improved learning concerning several dimensions of specialised language:

(Text: reading) C9: I liked everything because now I'm not reading like the Piupiu anymore [syllabic reading]. Before I was but now I'm not. (1CA7)

(Code: spelling) C16: I learned to make fewer spelling mistakes. (2ZM2)

(Text: vocabulary) C8: Classes enriched my vocabulary (2CA3).

(Text: process writing) C5: I started to write texts better and to organise them because ... Before PNEP I wrote one thing, then I talked about something else and then spoke of another and then referred to what I had said before. But with the PNEP I started organising things better (...) and I began to revise what I write. (4ARD9)

(Text: reading) C6: I think I improved my reading because before my reading was not good, it was only putting the letters together (4TM4) 
(Text: writing, specialised language) C4: I also learned not to repeat and he said and and, and, and so often (...) Also, instead of using he said I use he affirmed. (4ARD9).

(Text: reading) C9: I now understand texts better. I interpret them.

T: What do you mean by interpret?

C9: It's when you know what the text is talking about.

T: And did your interest in reading increase, decrease or it is in the same?

C9: Increased. In the past, I did not read a book and now I read three to four books each month. (4TM3_4)

(Text: reading, vocabulary) C3: Now I understand better all the words and what they mean.

T: When you want to know the meaning of words (...), which strategies do you use to discover to the meaning of words? There are various ways ... Do you remember?

C6: We see the context, the word root.

T: We see the context, see the word root ... and if you do not find what the word means, what do you do?

C10: Find it in the dictionary.

T: And if the word does not appear in your dictionary, where do you look it up?

C6: In the online dictionary. (4TM5)

\section{Which representations about the aim of literacy learning did students construct?}

We found clear perceptions of the usefulness of the learning constructed in the answers of $3 \mathrm{rd}$ and 4th graders, who associated specialised language learning at school with cultural dimensions of their own lives. They referred to the importance of language learning for their immediate learning, for their autonomy as learners and for cross-curricular learning:

C1: In PNEP we want to know more. We arrive home and we want to look up for more information [in the internet] to understand better. (4ARD6)

C2: In the PNEP classes one learns a lot about Portuguese and that is good for studying and for our learning. (4JP1)

Besides, they envisage their learning as relevant to prepare them for their future learning, and for their adult, social life:

C1: We learned contents in PNEP that we then go the fifth grade without difficulties. (4JP5)

C7: With PNEP the lessons we have improved a lot and I have improved my reading and writing, which are very important for our future, because, with God's help, we will have a profession. (4ARP5)

C10: I also really liked the Amazon Treasury lesson because I learned how to make a game and I learned to make the instructions and now I can make a game on another topic. (4ARG3)

C21: I liked these classes ... and the one I liked the most was the Côa Battle, because when I grow up I can go to [and participate in] a debate (3ARG3)

\section{Which features of the experienced process were perceived as relevant for literacy learning?}

Students' meanings about how they learned provided a very fruitful field for thematic analysis. In general, children expressed their perception that PNEP was a motivating and effective learning process. Furthermore, they perceived it as a singular experience, elaborating on their reasons in a very revealing way. 


\section{A motivating and effective process}

In students' voices, we clearly perceived a general very positive perception concerning the learning process. Generally, classes were experienced as easy and motivating, as this fourth grader affirms, 'I think that it was not difficult because nothing is difficult or boring when we are learning and are having fun. Everything is fun with lots of learning. (4ARP4). Students recurrently said that classes were very interesting and that they learned (very) well, and we found recurrent evidence for the idea that students found classes to be a different, challenging and engaging way of learning:

C2: I liked the PNEP classes because there were kind of challenges to learn (2ZM2)

C12: With the PNEP classes we began to learn better. (3LA8)

C9: PNEP was to discover new things and for us it were new adventures that we did (4ARD3).

We found rare examples of expression of learning difficulties:

C1: I enjoyed the milk cake recipe the least.

T: Why did you like that the least?

C1: Because we had a lot of work and it was a bit difficult.

T: Did you find it difficult?

C1: A bit.

C12: I didn't find that difficult. (1CA4)

In this case, a 1st grader expressed her difficulty with a task involving reading a recipe, also illustrating the expression one among otherwise very few instances of subjective opinion that was contrary to the group meaning that was being intersubjectively constructed.

\section{A singular learning process}

The perception that classes were different was cut-clear in children's voices, in most cases without having being confronted about that issue:

C2: Before PNEP, classes were all alike (...) we learned normally. (3LA7)

$\mathrm{C} 1$ : We were learning but in different ways from the usual ones. (3VL1)

C13: In PNEP classes, the teacher explains and we do different activities. We do not do worksheets; we do group work, we look for information in the internet. (4ARD5)

Children's contributions allowed the association of such difference to the enactment of a pedagogy constructed upon situated practice, explicit learning and transformed practice. However, the meanings children expressed re-shaped our preliminary theoretical ideas about situated practice in very significant ways.

\section{Situated practice: agency}

The analysis showed that learning was edified upon an intense activity. 1st graders said, Group: 'We worked a lot' (1CA1), which was a common opinion. Children identified such activity as a singularity of PNEP: 'C16: PNEP classes were different because they were more dynamic'. (3TM25). Their voices allowed us to understand that the textbook was not part of the activities in which they were involved: C2: 'No, we worked in other ... not with textbooks ... we worked with our ideas' (2AL1), a fact that a 4th grader also evoked to justify his perception that classes were not normal:

C3: In my opinion, PNEP was a funny way to learn, we learned more than by attending to a normal class as with the other teachers.

T: What do you mean by a normal class?

C3: A normal class is: 'Let's learn an issue' and then we read the textbook. With PNEP, we even learned more than by using the textbook. (4ARD1) 
Through their contributions, children helped us construct a clear idea of what happened instead. Students very frequently said that they did different activities and we perceived that their learning was clearly situated upon their own agency. Their interventions are full of varied and powerful activity verbs such as did, made, constructed, underlined, used, registered, recorded, selected, presented, chose, searched, discovered, among many others, inflected in the first person singular or plural, as illustrated in the examples that we use in the article.

\section{Situated practice: playfulness}

The analysis unveiled that the perceived singularity of the PNEP classes was deeply associated to the playfulness character of the literacy practices. This was the most surprising theme revealed by the analysis:

C6: In PNEP we did ... not exactly games but kinds of games that we learn to do things in a different manner and we can memorise that better in our heads.

P: Well, so PNEP introduced a way of seeing things and of keeping them in memory, is it?

C6: Yes.

P: Because of games?

C6: Yes. Through games we are able to see things better. When we played games we had fun and, at the same time, we also learned. (4ARD4-5)

All groups said that classes were fun and that they enjoyed themselves a lot when learning. In their voices, we perceive that games and role-play emerged as the most valuable dimension of the literacy learning process:

C14: We learned working games. (1CA3)

C7: I liked PNEP classes because we played games (2ZM2)

C12: I liked these classes because we learned new things in a playful manner. (3JR2)

Data showed that students valued games with rules and thematically related to their sociocultural reality. Their voices also revealed that they experienced a very structured form of play, controlled and assisted by teachers and oriented to the attainment of curricular goals. We found no evidence of child initiated and controlled literacy games. The following examples illustrate these findings at the same time that they evidence the existence of a subcategorisation in the experienced play.

Play in self-sustained literacy practice. Children referred to many instances of practice that were focused on literacy learning by itself, that is, literacy practices enacted to allow the learning and practice of different dimensions of specialised language (code, text, grammar). Students' voices make it clear that play situated such learning. A recurrent example of a play in self-sustained literacy learning among first graders was The Little Syllable:

C1: I liked Piupiu the most, the bird [doll] whose beak you shook.

T: And why did you like Little Syllable?

C1: Because it was a very funny game. (1CA4)

This is a game in which C2: 'You [teacher] said the words and we clapped our hands and then used a little doll to put [the corresponding number of] little circles [under the images corresponding to the oral words]' (1CM2_1). This game was played to help children C4: 'join and separate syllables' (1CA10), that is, to promote the development of phonologic awareness. Another first grader said that the class he liked the most was C6: 'Singular and plural' because 'we read and put the words in the corresponding boxes' (1CM1_3) so that they could infer about what distinguishes both and construct specialised knowledge about language. Other examples were versions of classic games, such as lotus or card games, used with a wide range of learning objectives, such as to introduce the written forms 
of common oral words (to help students memorise them in order to promote initial reading). Other games were adapted from well-known school tasks like the one referred to in the following excerpt:

Child 13: I think PNEP classes were fun and the part I liked the most was the spelling game Pay attention, hide, recall, write and check!

Teacher: Oh! Did you like that session? Do you know what you were learning in that session?

Child 13: Yes, it was learning that ... in a funny way, we can learn how to write the words and, when we have doubts, to better remember these words. (3AL4)

In the following case, the challenge comes in the form of pretend play. From what the student says, we perceive that the task aimed to promote the development of his public oral expression:

C6: I learned to express myself in front of more people. I am not now as embarrassed as before, because we did a play ... I chose a role ... I made a sword ... and I wrote notes of what I had to say in a paper for my colleagues to guess which character I was playing. (4ARD10)

Play in situated teleological literacy practice. The analysis also revealed other cases of literacy practices that were carried out with other goals beyond those strictly associated with literacy learning. We called these teleological literacy practices. In such situations, students made meanings which were immediately related to other curricular learning (or else non-curricular, but still socially relevant situations). In these cases, literacy practices were fundamental in the enactment of such learning goals; at the same time, these situations framed the learning of relevant dimensions of the specialised language involved in those practices, such as text reading, writing or specialised text genres. Children almost invariably describe these as playful practices.

In many cases, teleological literacy practice involved the assumption of a sociocultural role. For instance, a third grader said, C5: 'I liked a lot when we went to explain to our godchildren' (3AL1), referring to an activity aimed to introduce reading and writing to kindergarteners and in which third graders, who fully prepared the activity, assumed the teacher's role. Another third grader stated, C14: 'The class I liked the most was the news article that we wrote and sent to the newspaper (...). It was about the reading week [that had been held in school]' (3AL5), again a situation in which an adult role was played in a teleological literacy practice and during which they also learned about the specialised language of the news article, in this case, about its genre. A similar case can be found in the following transcript from a fourth grader: 'The class that I liked the most was that in which we made a yoghurt cake' (4JR2) because they had to read the recipe.

In the following example, playing assumed the form of a game that implied the training of Maths knowledge and the reading of instructions and leaning about this specialised textual genre:

T: But ... if you had to choose one [class], which would you choose?

C8: The banker's game.

T: And why The banker's game? What did you do in that class to like it so much?

C8: We played a game.

T: And what was the game about? (...)

Group: Maths.

C8: We played the game with the help of the instructions.

C9: It was Portuguese language and Maths.

T: Were the instructions Maths?

Group: No!

C: They were written in Portuguese.

Teacher Trainer: What kind of text were the instructions? 
Group: It was an instructional type of text. (2TM2)

Interestingly, some references helped us identify some other relevant features of situated teleological literacy practice as experienced by students. They revealed that such practices were valued when clearly centred on students' themselves or, otherwise, unappreciated when they distanced themselves from their interests, likes and dislikes. The transcript below, the teleological literacy practice was clearly situated in students' own emotions and personal interests. The student was highly motivated by the meanings being constructed, which were evidently more important for him than literacy contents (actually making them invisible):

C7: What I liked the most was doing Dad's text.

P: Why?

C: Because it was fun, I really like my father ...

T: Yes, it was something that you liked to do because it was for your father ...

C7: I learned new things that fathers feel. (2IL3)

Differently, in the following case we listen to a student expressing her negative opinion about a teleological literacy practice (to learn about plants in Science) that was the context of situated learning of specialised contents (text writing):

C10: The class that I liked the least was when we were always working plants, plants, plants, plants, plants ... the homework was also about plants. Plants were everywhere!

T: (...) But why didn't you like it? Was it tiring or was it boring or was it because you thought you were not going to learn anything from that?

C10: Well, in what concerns to learning, I did learn. But it was a bit tiring ... it was almost always plants, plants, plants, and I didn't find that class interesting at all. (...)

T: So now let me ask you something. What for did you have all this trouble? To learn how to write ...

C10: Texts.

T: (...) Do you think it was worthwhile or not?

C10: Look, before I didn't think well; now I think better ... Now I think all that hassle was ...

T: Useful?

C10: Useful to learn how to write texts better. (3LA6-7)

The subjective opinion is only apparently contradictory to the group meaning that was being intersubjectively constructed regarding the pedagogy experienced in PNEP. The group opinion was very favourable, and this student's negative appraisal of a teleological literacy practice reveals the boundaries of their experienced practices when fun (or, at least, personal satisfaction) were not involved at all. On the whole, these final examples underline the role of play (or, at least, of immediate personal relevance) in the construction of situated literacy practices.

\section{Situated practice: collaboration}

Data analysis also revealed that collaboration was recurrently mentioned and valued as a dimension of situated practice. It was very appreciated by students from all grades:

C9: I liked to work with everyone. (1AL4)

C11: What I liked the most was error hunting. I think I learned to write words that I did not know, I learned better with my colleagues. (2IL3)

C9: The part I liked the most in PNEP was group work (...) because when we work together we can do more things ... we have more ideas. (4JR3)

C13: In PNEP we learned to collaborate with our colleagues in group work and to give our opinion. (4ARG5) 
Collaboration was perceived as an important dimension of the singularity of the learning process. In the following contributions, obtained when a class of third graders were asked about the differences they perceived in PNEP classes, students (intersubjectively) revealed an acute awareness of the role of collaboration in their learning in PNEP and of how that diverged from Ms. H.'s usual classes. In this case, the PNEP teacher (interviewer) was not the usual class teacher (Ms. H.), a relatively common fact in the in-service programme due to the possibility that all teachers, including those who were not teaching, enrolled for their professional development requirements. In such cases, teachers did their supervised practices in another teachers' class. By listening to these students' voices, we understand that they preferred the new enacted curriculum for being collaborative, clearly associated to their agency. Furthermore, we understand how critical they are of Ms. H.'s usual classes, characterised by silence, quietness, attentiveness, individual work and rote memorisation:

C5: I think PNEP classes were different.

T: Why?

C5: Because we did several things.

T: Such as ...

C5: Such as group work. It's not every day that we do this!

C1: Oh! There was a big difference because in the other classes we have to be focused, we have to learn what's on the blackboard. In PNEP classes, it was not like that: We had the opportunity to try new things, of living things that we had not lived before, and I liked that.

C2: They were different because with Ms. H. everyone has to think for themselves, and in PNEP we worked in groups and that is not the same as Ms. H's classes.

C4: They were very different because we worked in groups and had to present what we wrote to the class, and with Ms. H. we did not do that.

C10: To me they were different because with Ms. H. we have to study, then we tell that to Ms. H. and then when we come here we need to have everything in our heads.

C9: With Ms. H. we work for ourselves, whereas in PNEP classes we can work in a group. For example, if we do not understand anything the other students can help us. (4JR3-5)

\section{Situated practice: ICT mediation}

The use of ICT devices to learn was frequently referred to as a novelty, thus another dimension of the singularity of the learning process that was highly valued by students. The following first grader's opinion echoed throughout all transcripts: 'I liked us writing our names in the computer' (1AR4). Among other examples, students' referred to the use of powerpoint to present their (collaborative) work and as well as to devices to record and listen to the stories they told (or invent) to tell each other:

C4: We told stories. (...)

T: And after telling stories in group, what did you do?

C4: We recorded them.

T: And then, you ...

C4: We listened to them (1CM2_2)

Internet was also very often referred to as having had a supportive role in the construction of students' knowledge:

C9: We learned to make research in the internet so that we could find things [information] quickly. (3VL2)

C6: PNEP classes were different because instead of listening to the teacher, to her explanations, I looked them up. (4ARG4) 
Students also valued the creation of their classes' blogs, to which they also referred as a context for new reading and writing practices and as source of learning, communication (among colleagues and beyond school) and enjoyment: C6: 'There are many things that we can learn with the sites in the internet and with other classes' blogs' (4JP13). One class used their blog to create a digital library, which motivated students a lot:

C14: I also did not know that digital books existed but since I learned that I have always being reading them. (...)

C7: I also did not know before that digital books existed but, as C14 said, I got used to reading them on our blog. (4JR9)

These voices evidence students' appraisal of the social nature of the reading and writing situations allowed by the use of digital devices, which appears to have stimulated their otherwise much appreciated collaborative forms of learning. At the same time, they illustrate their perceptions regarding the potential of ICT in the promotion of their autonomy as learners.

\section{Explicit learning. Top of form}

Although the interview scaffolded students to think more on their learning and on themselves as learners than on their teachers' explicit interventions, students often referred to their teachers' teaching. They said that they also liked classes because the teachers taught well:

C3: I liked PNEP classes because the teacher taught well (2ZM3);

C6: I liked the classes because the teacher explained herself in a very clear way (3VL1)

Interestingly, they also associated teachers' interventions to the perceived singularity in the PNEP lessons:

C13: I don't know how to explain, Teacher. Classes were the same but also different. Tt was different because PNEP classes explained us better, made things clearer (4TM21)

C1: The difference is the form of explaining... the form of explaining and of working. (4ARD6)

\section{Transformed practice}

Though in a lesser extent, we also found evidence of transformed practice as another feature of the learning experience that was valued by learners and perceived as different in PNEP classes. Agency, playfulness and, crucially autonomy, are associated with the following instances of transformed practice referred to by students, the first apropos the learning of grammar and the second, the learning of instructional texts:

C10: [explaining the differences in the classes] For example, adjectives ... Teachers say let's learn the adjectives and then we just do a worksheet about adjectives, whereas in PNEP we tried to do more for the adjectives. For example: to write a text to use adjectives. (4ARD6)

C10: I also liked the class about The Amazon Treasure because I learned to build a game and the rules of a game and now I can build a game about another theme. (4ARG3)

\section{Which representations about assessment of literacy learning did children construct?}

Some students referred to assessment during the interviews. We listened to a second grader say, 'I liked assessment' (2ARL1; 2), though unfortunately no further elaboration was requested from him. The most relevant contributions were again found in Ms. H.s group, in which learners pointed out self-assessment and the inexistence of testing as valuable and different dimensions of their learning process:

C7: Classes were different because we do not usually work together and because we never self-assess ourselves. (...)

C11: For me they were different because in Ms. H. lessons you have to be attentive, very attentive, do many tests, and that was not so in here. (4JR4) 
Assessment was the last topic in the in-service programme, which might have made it more difficult for teachers to put into in practice in a more consistent way. We do not evoke this 'technical detail' in order to justify the few evidence of children's representations about formative forms of assessment; instead, we intend to emphasise the actual value of these few instances, which we take as evidence of how formative forms of assessment are appealing for elementary students, especially in what concerns to assessment that is based on learners' own perspectives about their achievements.

\section{Discussion}

Our findings bring strong fundament to current conceptions of children as legitimate participants, interpreters and informants about issues concerning their life experience (Einarsdottir 2014; FargasMalet et al. 2010; Shaw, Brady, and Davey 2011) and they show the adequacy of using group interviews as tools for data collection when researching elementary school children in circumstances of adequate social and contextual support (Shaw, Brady, and Davey 2011). In effect, through the interviews we gathered rich data about children's representations about the literacy learning experience in which they participated, providing us with invaluable contributions to our research goals, centred on identifying relevant features of a literacy curriculum in elementary grades. The motivation with which students referred to their experience, evident in the vivid meanings of enjoyment and happiness they expressed, offered an encouraging starting point for us to fully analyse their representations about what, what for, how to learn literacy and to assess learning.

Despite not evidencing elementary students' actual literacy competence accomplished through the participation in PNEP, the analysis showed that students from all grades developed an impressive awareness of the specialised language knowledge, structured into code, text and grammar, which was the object of their learning. Children gave plenty of evidence of having expanded their vernacular meaning potential, and of having (re)conceptualised their knowledge in a conscious way. Their voices revealed how easily they identified and self-assessed such learning, identifying knowledge that was new or else improved, thus revealing a strong control of their developing thinking. It also was very clear that students envisaged such cognitive achievements to be valuable for their own future literacy practices as learners and as citizens. On the whole, the learning that students constructed made personal sense to them and students gave coherent signs of having developed their literacy knowledge in a fully linked manner to their communities, as they clearly perceived the object of their learning as a preparation for their future cultural life.

Considering that our learners were beginners in the learning of literacy, we take these to be powerful findings. They evidence the practicability of current curricular assumptions that defend need to sustain school learning upon specialised, differentiated forms of knowledge (Young 2013). Besides, they offer particular sound support to the conception of specialised language as the object of learning in the literacy curriculum for elementary grades aimed at preparing students for entering specialised academic learning, social integration and conscious autonomy (Pereira 2010b; Gee 2010; Halliday 1993; Schleppegrell 2004).

Our findings also corroborated the practicability of current curricular tenets concerning how to learn literacy and how to assess such learning, at the same time that they allowed us to re-examine and refine some such assumptions.

We consider students' robust representations about their specialised language learning altogether with their favourable perceptions about teachers' interventions as strong evidence of the adequacy of the pedagogical principle of explicit learning (Cope and Kalantzis 2009, 2010; The New London Group 2000; Rasinski and Padak 2004; Rupley, Blair, and Nichols 2009). We are inevitably led to deduce that students' learning was achieved through teachers' effective and explicit mediation. It is unlikely elementary students would have managed to construct such specialised knowledge by themselves, since they are apprentices of the essential tool for their autonomous learning, which is specialised language itself.

Our findings further corroborate the importance and the tenets that sustain the principle of situated (and transformed) practice (Cope and Kalantzis 2009, 2010; Dede 2000; The New London Group 2000). 
We perceived that active communities were highly appreciated, although often reported to have been settled and experienced for the first time during PNEP classes. That was also the case with the mediation of ICT devices to learn and communicate with others (and, therefore, to scaffold the construction of learning communities). It was clear that these students did not have a full-fledged digital literacy experience at school (not even in the PNEP classes) since the few reported experiences were often a complete novelty. This finding is in tune with the acknowledged tension there is between the traditional literacy practices in school and children's experience of multiliteracies out-of-school, in particular regarding digital practices, bringing further support to the claim that such gap is resolved by bringing digital practices (thus, students' real lives) into their classrooms (Edwards 2013, 2015). We also learned that students appreciate situations of (situated) transformed practice, in which specialised forms of language are used to make new meanings. However, our findings unequivocally point into the need to reconsider this theorisation of situated literacy practice in order to conceive of play as essential in the learning of literacy at elementary school grades.

The thematic analysis of children's representations unveiled the key role of play in their learning experience (Vygotsky 1979). Learners revealed that they played their way into the formal learning of literacy. A word is here relevant about emergent literacy, which defines the intense conceptualisation that pre-school children construct about literacy as a result of their interaction with and interest for literacy in their immediate sociocultural contexts (Adams 1990). Research thus suggests that late pre-schoolers are aware that literacy is a central dimension of their culture. They know that they will learn literacy at elementary school and expect to learn it their own way. Our data suggest that the literacy learning that our students experienced might have answered to that ontogenetic call by presenting itself as an extended, real-life learning game, one that is connected to learners own identities as real-life subjects, in clear consonance with Kravtsova's (2014) ideas about play in elementary grades. They constructed their learning by playing the literacy game as relevant repertoires of participation for their own cultural becoming and identity formation (Wood 2014). In each category of playful learning that we identified, students learned and trained rules and procedures that they perceived to be necessary in order to play literacy practices later on in their life, as captured in their declarations about the future value of their learning.

Play has also been explored as a dimension of ICT pedagogical use at school (Edwards 2013, 2015; Stephen and Plowman 2014), and although theirs was a restricted digital learning context, these students' enthusiasm supports the idea of introducing well-designed playful ICT devices for literacy learning in elementary grades.

We learned that students played to learn the curriculum that PNEP offered them, and we also learned that they did it in a highly structured manner, since the whole game was planned and controlled by teachers. Our data are therefore relevant to discuss the idea that play is theoretically and practically difficult to reconcile with pedagogy (Wood 2014). In effect, Martlew, Stephen, and Ellis (2011) report the study of the enactment of a play-based structured pedagogy in the first grade of elementary schools, following politically assumptions in Scotland. Their results illustrate the difficulties of reconciling play and pedagogy, showing that play sometimes became merely peripheral to the learning process, carried out in a separate space and time. Regarding this issue, Wood (2014) sustains that structured play pedagogies run the risk of weakening students' affective connection to learning. None of these seem to have happened, at least as perceived by learners in our study: playful literacy learning was overwhelmingly present and students fully engaged in them, as they apparently do with any other beginning forms of culture that they want to learn in order to become enculturated (Van Oers 2014). We attribute the tremendous favourable opinions and good feelings which children associated to their structured learning experience to the fact that the whole literacy game was responsive to their ontological play dispositions, which makes of rule-governed, reality-related play their preferred mode of learning (Van Oers 2014; Kravtsova 2014). We take the link between cognition and affect that we found in students' representations about the literacy knowledge they constructed as sign of the experienced of a balanced literacy curriculum (Rasinski and Padak 2004). 
Our findings show that play situated the meanings children created, which, in turn, made specialised forms of language useful and, apparently, easy to learn (Gee 2004, 2007, 2010). We consider that they are actually of particular relevance in discussing Gee's ideas about what specialised language are and 'game-like learning' (Gee 2010, 189). The pedagogical insights that Gee developed upon his research of videogames (Gee 2004) led him to conclude that 'specialist language in any domain - games or science - has no situated meaning unless and until one has "played the game"' (Gee 2010, 188). It also led him to conclude that such forms of learning 'could exist in school (...). But they don't' (Gee 2010, 184). Our findings suggest that a playful form of learning is a welcome and effective ingredient in the pedagogy that prepares elementary students for later, specialised forms of learning. We can now contend that the theoretical conception of situated and transformed practice presented by The New London Group (2000) and reinforced in Cope and Kalantzis $(2009,2010)$ seem to be limited in what concerns to elementary students' learning by not acknowledging the role of play as the key dimension of learning practice in this life period, an idea that clearly aligns with the argument that, in their transition to formal learning, 'children need more challenging forms of play that support progression towards social and symbolic complexity' (Wood 2014, 153).

A final word is due about self-assessment, as valued by some of our interviewees. We believe that such appreciation can be now reinterpreted as a consequence of having had an active role in the game that was being played, which offered learners' the opportunity to involve their perspectives in the whole process and to extend their agency into self-regulatory dimensions, as pointed out in research that focuses on play (Carr 2014; Meyers and Berk 2014).

On the whole, students' perceptions about the way they learned and were assessed clearly show appreciation of the experienced pedagogy of literacy, which they perceived as different from the classes that PNEP aimed to replace. The later insinuate themselves as being strictly mechanical and characterised by compulsory tasks with strictly fixed rules that do not offer actors any degrees of active engagement and autonomy (Van Oers 2014), as apparently was the case of Ms. H.s classes, and perhaps much too serious or adult-like, such as the class on plants.

\section{Conclusions}

Our research identified effective features of a curriculum for literacy learning in the elementary grades from the perspectives of students who were involved in one exceptional literacy-learning experience. On the whole, our model corroborates but also amplifies our initially assumed sociocultural tenets. We have concluded that the understanding of specialised language that structures the learning contents into code, text and grammar emerges as a suitable content basis for an elementary literacy curriculum. This set of contents revealed to be flexible enough to adapt to every school grade, as all students showed to be aware of having learned specialised knowledge in any of these domains. Our findings also suggest that, as they see it, structured, playful situated practice in collaborative and ICT mediated contexts, in which students learn explicitly and are formatively (self)-assessed, edify a very adequate literacy pedagogy.

As such, our conclusions bring fundament to curricular claims for pushing the literacy learning 'beyond the basics' but not 'into an adult like' learning curriculum in elementary education. Another important implication of our conclusions concerns the restrictedness and potential inadequacy of curricular conceptualisations for literacy learning elementary school that have emerged in the age of standards, testing and accountability.

We should acknowledge, however, some restrictions in the literacy curriculum as experienced by these children as, for instance, socio-critical dimensions of meaning making (Cope and Kalantzis 2009, 2010; Vasquez 2014) or the multimodal dimensions of specialised languages (Kress 2010) were not studied at all. Also, some limitations exist in the study that we developed. Although the data were powerful and rich in insights for conceiving a curriculum for elementary school literacy education, our research was confined to students' perspectives captured in a deferred moment from the learning process itself. Longitudinal ethnographic inquiries of educational practices are now needed that might 
deepen the knowledge about such a curriculum alive and study students' effective literacy competence that is thereby achieved. One query stands as particularly important in order to fully understand our research agenda. It concerns the enactment of play as pedagogy. In Wood's (2014) terms, the experience that we researched illustrated a quasi-technicist version of play. Literacy learning was framed by a curriculum that was politically instituted (though mediated by an academic institution), in the development of which play had an instrumental role. Yet, play as pedagogy was not captured in any political statement that founded PNEP and was not explicitly discussed with teachers involved at all; it was only implicitly present in the practical examples that teachers studied with, first at the university and then with trainers at schools. So, How come teachers made such an effective instrumental use of play if it was theoretically invisible for them?

\section{Disclosure statement}

No potential conflict of interest was reported by the authors.

\section{Funding}

The first author was funded by the Portuguese National Agency for Science and Technology [grant number SFRH/ $\mathrm{BSAB} / 1440 / 2014]$.

\section{Notes on contributors}

Iris Susana Pires Pereira is a professor of literacy education in the Department of Integrated Studies in Literacy, Didactics and Supervision at the Institute of Education, University of Minho, Campus de Gualtar, 4710-057 Braga, Portugal. Her interests centre on literacy education for early childhood \& primary school grades (including digital literacy) and teacher education. She is a member of CIEd (Centre of Research for Education).

Xosé Antón González Riaño is a professor of literacy education in the Department of Sciences of Education, Faculty of Teacher Development and Education, University of Oviedo, Spain. His interests centre on language education, multilinguism, interculturality and sociolinguistic dimensions of language education.

\section{References}

Adams, M. J. 1990. Beginning to Read: Thinking and Learning about Print. Cambridge, MA: MIT Press.

Anderson, K. 2008. "Intersubjectivity." In The Sage Encyclopaedia of Qualitative Research Methods, edited by L. M. Given, 467-468. Thousand Oaks, CA: Sage.

Bahktin, M. M. 1986. Speech Genres and Other Late Essays. Translated by Vern W. McGee. Austin: University of Texas Press.

Black, P., and D. William. 1998. "Assessment and Classroom Learning." Assessment in Education: Principles, Policy and Practice 5 (1): 7-74. doi:10.1080/0969595980050102.

Braun, V., and V. Clarke. 2006. "Using Thematic Analysis in Psychology." Qualitative Research in Psychology 3 (2): 77-101.

Brooker, L., M. Blaise, and S. Edwards, eds. 2014. The Sage Handbook of Play and Learning in Early Childhood Education. London: Sage.

Broström, S. 2006. "Children's Perspectives on Their Childhood Experiences.” In Nordic Childhoods and Early Education, edited by J. Einarsdottir and J. Wagner, 223-255. Greenwich, CT: Information Age Publishing.

Bruner, J. 1986. Actual Minds, Possible Worlds. Cambridge, MA: Harvard University Press.

Carr, M. 2014. "Play and Playfulness: Issues of Assessment." In The Sage Handbook of Play and Learning in Early Childhood Education, edited by L. Brooker, M. Blaise, and S. Edwards, 264-275. London: Sage.

CNA (National Commission for the Coordination and Support of PNEP). 2006. Documentos orientadores de circulação interna [Support documents with restricted distribution]. Lisboa (ms).

Cohen, L., L. Manion, and K. Morrison. 2011. Research Methods in Education. 6th ed. London: Routledge.

Coltheart, M., B. Curtis, P. Atkins, and M. Haller. 1993. "Models of Reading Aloud: Dual-route and Parallel-distributed Processing Approaches.” Psychological Review 100: 589-608. doi:10.1037/0033-295X.100.4.589.

Cope, B., and M. Kalantzis. 2009. "Multiliteracies: New Literacies, New Learning." Pedagogies 4 (3): $164-195$. doi:10.1080/15544800903076044. 
Cope, B., and M. Kalantzis. 2010. “A Multiliteracies Perspective on the New Literacies." In The New Literacies: Multiple Perspectives on Research Pratice, edited by Elizabeth A. Baker, 61-87. New York: Guilford Press.

Dede, C. 2000. “Emerging Influences of Information Technology on School Curriculum.” Journal of Curriculum Studies 32 (2): 281-303. doi:10.1080/002202700182763.

Edwards, S. 2013. "Digital Play in the Early Years: A Contextual Response to the Problem of Integrating Technologies and Play-Based Pedagogies in the Early Childhood Curriculum.” Technology, Pedagogy and Education 21 (2): $199-212$. doi:10.1080/1350293X.2013.789190.

Edwards, S. 2015. "New Concepts of Play and the Problem of Technology, Digital Media and Popular-culture Integration with Play-based Learning in Early Childhood Education." Technology, Pedagogy and Education 25 (4): 513-532. do i:10.1080/1475939X.2015.1108929.

Einarsdottir, J. 2014. "Children's Perspectives on Play." In The Sage Handbook of Play and Learning in Early Childhood, edited by L. Brooker, M. Blaise, and S. Edwards, 319-329. Los Angeles, CA: Sage.

Ellis, A. W. 1989. Reading, Writing and Dyslexia. Hove: LEA Publishers.

Fargas-Malet, M., D. McSherry, E. Larkin, and C. Robinson. 2010. "Research with Children: Methodological Issues and Innovative Techniques." Journal of Early Childhood Research 8 (2): 175-192. doi:10.1177/1476718X09345412.

Flower, L., and J. R. Hayes. 2003. "A Cognitive Process Theory of Writing." In Cross-talk in Comp Theory, edited by V. Villanueva, 2nd ed, 273-297. Urbana: NCTE.

Gee, J. P. 2004. Situated Language and Learning. A Critique of Traditional Schooling. New York: Routledge.

Gee, J. P. 2007. Social Linguistics and Literacies. Ideology in Discourse. 3rd ed. London: Taylor \& Francis.

Gee, J. P. 2010. "A Situated-sociocultural Approach Lo Literacy and Technology." In The New Literacies: Multiple Perspectives on Research Pratice, edited by E. A. Baker, 165-193. New York: Guilford Press.

Halliday, M. A. K. 1993. “Towards a Language-based Theory of Learning." Linguistics and Education 5: 93-116. doi:10.1016/0898-5898(93)90026-7.

Halliday, M. A. K., and J. Martin. 1993. Writing Science. Literacy and Discursive Power. London: Falmer Press.

Heath, S. B. 1983. Ways with Words. Language, Life, and Work in Communities and Schools. Cambridge: Cambridge University Press.

Holquist, M. 2002. Dialogism. London: Routledge.

Irwin, J. W. 2007. Teaching Reading Comprehension Processes. 3rd ed. Boston, MA: Allyn and Bacon.

Kravtsova, E. 2014. "Play in the Non-classical Psychology of L. S. Vygotsky." In The Sage Handbook of Play and Learning in Early Childhood Education, edited by L. Brooker, M. Blaise, and S. Edwards, 21-30. London: Sage.

Kress, G. 2010. Multimodality. A Social Semiotic Approach to Contemporary Communication. Abington: Routledge.

Krueger, R. A. 1991. El grupo de discusión: guía practico para la investigación aplicada [Focus groups: A practical guide for applied research]. Madrid: Pirámide.

Lewis, A. 1992. “Group Child Interviews as a Research Tool”' British Educational Research Journal 18 (4): $413-421$. doi:10.1080/0141192920180407.

Martlew, J., C. Stephen, and J. Ellis. 2011. "Play in the Primary School Classroom? The Experience of Teachers Supporting Children's Learning through a New Pedagogy." Early Years: An International Research Journal 31 (1): 71-83. doi:10 $.1080 / 09575146.2010 .529425$.

Meyers, A. B., and L. E. Berk. 2014. “Make-believe Play and Self-regulation.” In The Sage Handbook of Play and Learning in Early Childhood Education, edited by L. Brooker, M. Blaise, and S. Edwards, 43-55. London: Sage.

Morgan, M., S. Gibbs, K. Maxwell, and N. Britten. 2002. “Hearing Children's Voices: Methodological Issues in Conducting Focus Groups with Children Aged 7-11 Years." Qualitative Research 2: 5-20. doi:10.1177/1468794102002001636.

The New London Group. 2000. "A Pedagogy of Multiliteracies." In Multiliteracies, edited by B. Cope and M. Kalantzis, 19-37. London: Routledge.

Pereira, Í.S.P. , ed. 2010a. O ensino do português no $10^{\circ}$ ciclo do ensino básico. Construção de saberes profissionais no contexto do PNEP e do novo programa de português, Vol. 1 [Teaching Portuguese in elementary education. Professional knowledge construction in the context of PNEP and the new language curriculum, Vol 1], 9-44. Braga: Instituto de Educação da Universidade do Minho - Serviço de Publicações.

Pereira, Í. S. P. 2010b. "Um desenho global para o ensino da língua no 1. o ciclo do ensino básico" [A global design for language teaching in elementary education]. In O ensino do português no $10^{\circ}$ ciclo do ensino básico. Construção de saberes profissionais no contexto do PNEP e do novo programa de português, Vol. 1 [Teaching Portuguese in elementary education. Professional knowledge construction in the context of PNEP and the new language curriculum, Vol 1], edited by Í.S.P.Pereira, 45-156. Braga: Instituto de Educação da Universidade do Minho - Serviço de Publicações.

Rasinski, T., and N. Padak. 2004. "Beyond Consensus-beyond Balance: Toward A Comprehensive Literacy Curriculum." Reading and Writing Quarterly 20 (1): 91-102. doi:10.1080/10573560490242813.

Reid, W. A. 1999. Curriculum as Institution and Practice. Essays in the Deliberative Tradition. Mahwah, NJ: Lawrence Erlbaum.

Rupley, W. H., T. R. Blair, and W. D. Nichols. 2009. "Effective Reading Instruction for Struggling Readers: The Role of Direct/Explicit Teaching." Reading \& Writing Quarterly: Overcoming Learning Difficulties 25 (2-3): $125-138$. doi:10.1080/10573560802683523. 
San Fabián, J. 2014. Evaluar programas socioeducativos en tiempos de crisis. Un enfoque organizacional. [Assessing socioeducational programs in a time of crisis. An organizational focus]. Oviedo: Ed. Trabe.

Saywitz, K. J., and L. B. Camparo. 2014. "Interviewing Children: A Primer." In The Sage Handbook of Child Research, edited by Gary B. Melton, Asher Ben-Arieh, Judith Cashmore, Gail S. Goodman, and Natalie K. Worley, 371-391. London: Sage.

Schleppegrell, M. J. 2004. The Language of Schooling. A Functional Linguistics Perspective. Mahwah, NJ: Lawrence Erlbaum Associates.

Schwab, J. J. [1970] 2013. “The Practical: A Language for Curriculum.” Journal of Curriculum Studies 45 (5): $591-621$. doi:10.1080/00220272.2013.809152.

Shaw, C., L.-B. Brady, and C. Davey. 2011. Guidelines for Research with Children and Young People. London: National Children's Bureau.

Stephen, C., and L. Plowman. 2014. "Digital Play." In The Sage Handbook of Play and Learning in Early Childhood Education, edited by L. Brooker, M. Blaise, and S. Edwards, 330-341. London: Sage.

Van Oers, B. 2014. "Cultural-historical Perspectives on Play: Central Issues." In The Sage Handbook of Play and Learning in Early Childhood Education, edited by L. Brooker, M. Blaise, and S. Edwards, 56-66. London: Sage.

Vasquez, V., ed. 2014. Negotiating Critical Literacies with Young Children: 10th Anniversary Edition (Language, Culture, and Teaching Series). New York: Routledge Press.

Vygotsky, L. S. 1979. El desarrollo de los procesos psicológicos superiores [The Development of Higher Psychological Processes]. Barcelona: Crítica.

Vygotsky, L. S. 1995. Pensamiento y lenguaje [Thought and Language]. Barcelona: Paidós.

Watts, M., and D. Ebbutt. 1987. "More than the Sum of the Parts: Research Methods in Group Interviewing." British Educational Research Journal 13 (1): 25-34. doi:10.1080/0141192870130103.

Wertsch, J. V. 1991. Voices of the Mind: A Sociocultural Approach to Mediated Action. Cambridge, MA: Harvard.

Wood, E. 2014. “The Play-pedagogy Interface in Contemporary Debates.” In The Sage Handbook of Play and Learning in Early Childhood Education, edited by L. Brooker, M. Blaise, and S. Edwards, 145-156. London: Sage.

Yoon, K. S., Duncan, T., Lee, S. W.-Y., Scarloss, B., \& Shapley, K. 2007. Reviewing the evidence on how teacher professional development affects student achievement(Issues \& Answers Report, REL 2007-No. 033). Washington, DC: U.S. Department of Education, Institute of Education Sciences, National Center for Education Evaluation and Regional Assistance, Regional Educational Laboratory Southwest. Retrieved from http://ies.ed.gov/ncee/edlabs

Young, M. 2013. “Overcoming the Crisis in Curriculum Theory: A Knowledge-based Approach.” Journal of Curriculum Studies 45 (2): 101-118. doi:10.1080/00220272.2013.764505. 